\title{
The Argentine Competition Law and its Enforcement
}

by Germán Coloma (CEMA University, Buenos Aires, Argentina) *

\begin{abstract}
This article analyzes the basic characteristics of the Argentine competition law and the way in which it has been enforced in several important antitrust cases. We begin with a section that introduces the evolution of the law, followed by another section about the basic economic and legal principles underlying that law. The rest of the article describes the enforcement of the law, in a number of cases that involve collusive practices, exclusionary practices, vertical restraints, abuses of dominant position, and mergers.
\end{abstract}

\section{Resumen}

Este trabajo analiza las características básicas del derecho argentino de defensa de la competencia y el modo en el cual ha sido aplicado en varios casos importantes. Empieza con una sección sobre la evolución del derecho antitrust argentino, seguida de otra sobre los principios económicos y jurídicos básicos que están detrás de dicho derecho. El resto del artículo describe la aplicación de la ley argentina de defensa de la competencia, en una serie de casos sobre prácticas colusivas, prácticas exclusorias, restricciones verticales, abusos de posición dominante, y operaciones de concentración económica.

JEL Classification Number: K21, L40.

Keywords: Competition law, antitrust, Argentina.

The aim of this paper is to analyze the basic characteristics of the Argentine competition law and the way in which it has been enforced throughout the years. In order to do that, we will first include a short historical note about the different competition rules that existed in Argentina since 1933, ending with the enactment of the current legislation (which is Act No. 25,156, approved by the Argentine Congress in 1999). The second section of the paper contains an analysis of the main features of the current Argentine antitrust system, and its similarities and differences with the schemes that exist in other countries (especially the United States and the countries

\footnotetext{
* The views and opinions expressed in this publication are those of the author and are not necessarily those of CEMA University.
} 
belonging to the European Union).

The rest of the paper contains a review of the main antitrust cases that took place in Argentina. There is a section on collusive practices, another one about horizontal exclusionary practices, another one about vertical restraints, and another one about exploitative abuses of dominant position. Finally, the paper includes the analysis of several merger cases, both horizontal and vertical, followed by a last section that summarizes the whole study and develops some concluding remarks.

\section{Historical overview}

The antitrust legislation in Argentina began in the year 1933, when the Act No. 11,210 was approved by the Argentine Congress. That act was clearly inspired in the provisions of the US antitrust law, since its two first articles were virtually a translation of sections 1 and 2 of the Sherman Act. Additionally, the act contained the enumeration of a series of "monopoly practices", which were in general interpreted by the doctrine as specific cases that had to be included into the general principles established in the first two articles of the act.

Act 11,210 was replaced by Act 12,906 in 1946. Article 1 of this new act prohibited the practices tending to create a monopoly or to maintain a monopoly, while article 2 included a list of actions that were considered to be special monopoly practices. The interpretation of these provisions was that they could be forbidden although they were not included in the general type that was described by article 1 , since many of the so-called "special monopoly practices" referred to concerted collusive practices that were not part of the general concept of monopolization. Like its predecessor, Act 12,906 was considered to be part of the Argentine criminal law, although it established the need to follow an initial administrative procedure under the authority of the Department of Commerce of Argentina. To apply penalties, however, the Secretary of Commerce had to present a claim before the judicial authorities, which were the ones who ultimately decided on the matters under analysis.

Both Act 11,210 and Act 12,906 had a very scarce enforcement, and the 
Argentine case law only tracks record of four cases that ended in penalties during a period of forty-eight years of application of these two rules ${ }^{1}$. It was probably because of this that in the year 1980 a new competition law was enacted, through Act No. 22,262, also called the "Competition Defense Act". That rule created the first specific antitrust agency in Argentina, which is the National Commission for the Defense of Competition (CNDC). It also implied a movement towards rules that were closer to the European standards, since articles 1 and 2 of Act 22,262 were clearly inspired by articles 85 and 86 of the Treaty of Rome ${ }^{2}$.

With the adoption of the provisions of Act 22,262, the Argentine antitrust case law began to grow, and it also became much more compact and coherent. This was largely due to the fact that the procedures established by the act were strictly administrative, and therefore all the antitrust cases passed before the CNDC. This helped to develop some homogeneous criteria about which practices were anticompetitive and which practices were not, and in many ways those criteria were also compatible with the main international antitrust standards. The decisions taken by the CNDC, however, were not enough to close the antitrust cases. In fact, they were mere opinions that had to be endorsed by the Secretary of Commerce, which was the true enforcing authority of the competition act. During the years of application of Act 22,262, however, the CNDC's opinions were always endorsed by that secretary, and in fact it is possible to consider that there was a complete identity between the CNDC's opinions and the corresponding decisions of the Secretary of Commerce.

In August 1999, the Act No. 22,262 was replaced by the Act No. 25,156, which is the current competition defense act of Argentina. This new rule kept the majority of the substantial characteristics of its predecessor, especially in what concerns the characterization of anticompetitive practices. The dominant Argentine antitrust doctrine therefore considers that the case law developed between 1980 and 1999 is still valid nowadays. The most important innovation introduced by Act

\footnotetext{
${ }^{1}$ This information appears in Cabanellas (2005), chapter 1.

${ }^{2}$ Articles 85 and 86 of the Treaty of Rome (1957) were identical to the current articles 81 and 82 of the European Community Treaty, which are the basis of the European Union competition law.
} 
25,156 , however, was the enactment of a merger notification procedure, under which the main mergers and acquisitions that affect the Argentine markets have to be analyzed and approved (or prohibited) by the competition authority. Act 25,156 also created a new antitrust agency, whose name is "National Court for the Defense of Competition" (TNDC). This court was designed to replace the previously existing CNDC. The main difference between the CNDC and the TNDC is that the latter is supposed to be a more independent agency, since its decisions do not have to be endorsed by the Secretary of Commerce. At the beginning of the year 2007, however, the TNDC was still pending to be organized, and all the antitrust cases decided under the Act 25,156 have been analyzed by the authorities established by the old competition act (that is, by the CNDC and the Secretary of Commerce) ${ }^{3}$.

\section{Characteristics of the Argentine competition law}

As we mentioned in the previous section, the Argentine competition law follows the basic antitrust standards set by the European Community Treaty in their articles 81 and 82 . Because of that, the two main offenses under the Argentine competition law are the lessening of competition and the abuse of a dominant position (article 1, Act 25,156). However, as Cabanellas (2005) mentions, the way in which these two offenses are defined in the Argentine competition act allows for a certain overlapping between them. This is because, unlike the European Union law, the Argentine competition law does not require that the anticompetitive practices that fall into the concept of "lessening of competition" are concerted practices among two or more undertakings. It is therefore possible that a unilateral anticompetitive practice (for example, an exclusionary practice such as predatory pricing or entry deterrence) is considered at the same time a lessening of competition and an abuse of a dominant position.

Another requirement that the Argentine competition act includes in its article

\footnotetext{
${ }^{3}$ In fact, the secretary in charge of enforcing the competition defense act has changed throughout the years. In the period 1996-1999, for example, the CNDC depended on the Secretary of Commerce, Industry and Mining. Between the years 2000 and 2003, it depended on the Secretary of Competition Defense, while in the period 2003-2006 the official in charge was the Secretary of Technical Coordination.
} 
1 is that, in order to be illegal, anticompetitive practices have to be able to generate "damage to the general economic interest". This concept, which is not directly defined by the act, has been interpreted by the CNDC and the Argentine courts in different ways. The most widespread interpretation has associated it with the economic concept of "total surplus", that is, with the sum of the consumers' surplus and the producers' profit generated in a market ${ }^{4}$. This idea implies that, in order to be illegal, a business practice has to be, at the same time, anticompetitive (in the sense that it implies a lessening of competition or an abuse of dominance) and inefficient (in the sense that it generates a reduction in the economic surplus generated in the relevant market). The concept of "general economic interest" is also opposed to the concept of "private interest", emphasizing the idea that an anticompetitive practice has to affect the market as a whole and not only the distribution of a given surplus between buyers and sellers.

Article 2 of the current Argentine competition act contains a list of fourteen different types of anticompetitive practices. This list, however, is not taxative, in the sense that other practices can be considered illegal if they enter into the general definition of article 1. Similarly, a business practice that falls into any of the types of article 2 is not considered illegal if it does not enter into the general definition of article 1 (that is, if it does not imply lessening competition or abusing a dominant position or it does not generate damage to the general economic interest). The Argentine antitrust law, therefore, does not have any anticompetitive practice that is considered per se illegal, and all the offenses to the competition rules have to be analyzed under a "rule of reason" that requires showing damage to the general economic interest.

Although the Argentine competition act does not define what an abuse of a dominant position is, its article 4 does contain a definition of the concept of "dominant position". Under that definition, a person enjoys a dominant position when he or she "is the only supplier or buyer in the ... market or ... when, without being the only one, he or she is not exposed to substantial competition or when, because of

\footnotetext{
${ }^{4}$ That interpretation appears in a document issued by the CNDC (1997), and it has also appeared in several sentences of the Argentine Court of Appeals on Criminal Economic Matters.
} 
the vertical or horizontal degree of integration, he or she is able to determine the economic feasibility of a competitor or participant in the market". In order to establish if that standard is fulfilled by a certain undertaking in a concrete case, article 5 of the Act No. 25,156 establishes that there are three circumstances to be considered, which are the extent to which the relevant goods or services may be replaced by other goods or services, the extent to which regulatory restrictions limit the access of products or suppliers or buyers to the relevant market, and the extent to which a firm has the power to unilaterally affect prices or to restrict the supply or demand in the market (and the extent to which its competitors are able to offset that power).

Following the European antitrust tradition, the Argentine competition authorities have considered that the illegal abuses of dominant position can either be exclusionary or exploitative ${ }^{5}$. In cases of exclusionary abuses of dominant position, the anticompetitive behavior punished by the law is the use of a dominant position to exclude competitors (either real or potential). In cases of exploitative abuses of dominant position, conversely, what is illegal is the imposition of prices and commercial conditions that are different to the ones that would exist if there was effective competition in the market.

As we mentioned in the previous section of this article, the current Argentine competition act has introduced a merger notification procedure, which began to operate in 1999. Together with this procedure, the act established a standard to analyze when a merger is anticompetitive, and has therefore to be prohibited or conditioned by the antitrust authority. That standard is set by article 7, and it strongly resembles the one that appears in section 7 of the Clayton Act, which is the rule that governs the issue in the United States. In order to be prohibited in Argentina, a merger has to lessen, restrict or distort competition, in a manner that may generate damage to the general economic interest. This criterion differs from the one that is used in the European Union, under which mergers are prohibited if they create or reinforce a dominant position in a market.

\footnotetext{
${ }^{5}$ For a definition of these two classes of abuse of dominance in the European context, see Neumann (2001), chapter 3 .
} 
The Argentine competition law concerning mergers also has a strong point of connection with the US law because the Argentine antitrust authorities have issued a set of guidelines that is very similar to the horizontal merger guidelines issued in the United States by the Department of Justice and the Federal Trade Commission ${ }^{6}$. Those guidelines have sections that refer to the definition of relevant markets, the measurement of market concentration, the nature of the firms that compete in the relevant markets, the entry barriers, and the efficiency gains generated by a merger. A relatively innovative topic that those guidelines have is an explicit consideration of imports, which is one of the sources of competition that is more frequently analyzed by the CNDC when it deals with horizontal mergers that affect markets of internationally tradable products.

The other distinctive characteristics of the Argentine antitrust law have to do with the procedural aspects of the competition act's enforcement. As we mentioned in section 1 of this article, the Argentine antitrust system is based on the existence of a single competition agency which at the same time investigates the anticompetitive conduct cases, decides on the merits of those cases, and authorizes and/or prohibits mergers. The decisions of that agency can be appealed before the judicial courts, but all the antitrust processes have to begin before the administrative competition agency.

Unlike most European competition agencies, the Argentine CNDC has not established any procedure of authorization of possibly anticompetitive practices. All cases of anticompetitive conduct are therefore analyzed as the result of a complaint of a private party or are initiated ex officio by the CNDC (when that agency believes that a certain economic agent or group of agents is guilty of an anticompetitive practice). Previous authorization, conversely, is required when there is a merger that surpasses a certain sales threshold (which is currently set in 200 million Argentine pesos) and a certain transaction threshold (which is currently set in 20 million Argentine pesos) ${ }^{7}$.

When a person or firm is found guilty of an antitrust offense, the possible penalties established by the Argentine competition act are a fine of up to 150 million

\footnotetext{
${ }^{6}$ The Argentine merger guidelines were approved by Resolution 164/01, issued by the Secretary of Competition Defense.

${ }^{7}$ These are approximately equivalent to 67 million US dollars and 6.7 million US dollars, respectively (using the peso-dollar exchange rate of the year 2006).
} 
Argentine $\operatorname{pesos}^{8}$, and an order to cease and desist of the practice deemed illegal. In some cases, both penalties are applied jointly. The defendant in an anticompetitive conduct case can also offer a commitment to stop the practice under analysis, and the case can end with the acceptance of that commitment by the antitrust agency. Of course, the case can also end with the acceptance of the defendant's explanations by the competition authority, in which case the defendant is not considered guilty of any anticompetitive practice.

In merger cases, no fines are applied, since mergers are always analyzed before they take place ${ }^{9}$. The possible decisions of the antitrust agency in those cases are the unconditioned approval of the merger, the approval of the merger under certain structural or behavioral conditions to be fulfilled by the merging parties, and the complete prohibition of the merger. The most common structural remedies that appear in merger cases are obligations to divest part of the newly merged entity, through the sale of a certain number of shares, outlets, plants, trademarks or other equivalent assets. The most common behavioral remedies, in turn, consist of prohibitions to discriminate between different customers or suppliers, requirements to give access to certain essential facilities to competitors, and requirements to give customers the option to change their supplier ${ }^{10}$.

\section{Collusive practices}

As in many countries of the world, collusion is one of the main antitrust offenses in Argentina. This idea appears quite clearly in Act 25,156, whose article 2 characterizes at least six types of conduct that can be considered collusive. These are the ones mentioned in paragraphs "a", "b", "c", "d", "e" and "h", which state that practices such as price fixing, quantity fixing, horizontal market division, bid rigging,

\footnotetext{
${ }^{8}$ These are roughly equivalent to 50 million US dollars (using the peso-dollar exchange rate of the year 2006).

${ }_{9}^{9}$ In fact, merger cases always begin before the mergers take place, but the actual approval or prohibition can occur after the merger has been consummated. This point has been criticized by some commentators. See, for example, OECD (2006), chapter 6.

${ }^{10}$ The only fines that are sometimes applied in merger cases have to do with situations of late notification, or situations in which firms refuse to give some essential information to the antitrust authority.
} 
horizontal agreements to restrict investments and horizontal agreements to restrict research and development can all be considered anticompetitive, provided that they fall into the general definition given by article 1 .

Although the Argentine antitrust law does not punish any anticompetitive practice on a per se basis, the CNDC and the courts of appeals that have analyzed overt collusion cases have always found price fixing, quantity fixing, bid rigging and horizontal market divisions to be illegal, when they considered that those practices were adequately proved. An early example of that idea can be found in "Silos Areneros de Buenos Aires vs. Arenera Argentina and others" (1986), in which a group of sand maufacturers was fined for having established production quotas, through an agreement that also included the trade unions that represented the workers who transported the sand through ships.

Another significant collusion case is "Lara Gas and others vs. Agip and others" (1993), in which a group of distributors of liquefied petroleum gas (LPG) was fined for having practiced a market division that restricted competition among them. This case was particularly important because it reached the Argentine Supreme Court, who had to analyze the question whether the general economic interest was actually damaged by the agreement among the accused LPG distributors. This Supreme Court sentence is relevant in the Argentine antitrust case law because it established the principle that, if it is clear that the market conditions would be more favorable to consumers without the agreement, then the general economic interest has been damaged, although it is not possible to actually measure the amount of that damage.

The most important price-fixing case analyzed by the CNDC, which also ended in a fine to be paid by the defendants, is "AGP vs. CCAP and others" (1996), in which the main stowing companies of the port of Buenos Aires were punished for having fixed a uniform fee for each container stowed by them. Finally, the most important bid-rigging case (which was also closed with substantial fines) is "CNDC vs. Air Liquide and others" (2005), in which a group of oxygen producers was punished for having coordinated among themselves their bids in certain auctions organized by several Buenos Aires public hospitals (when they bought oxygen for 
medical purposes).

If the basic Argentine antitrust doctrine is relatively harsh when overt collusion is detected, it is also relatively conservative in cases of covert collusion. In "Department of Energy vs. YPF, Esso and Shell" (1994), for example, the CNDC set the principle that conscious parallelism is not enough to prove collusion, in a case in which the three main fuel refiners that operated in Argentina were accused of price fixing. This principle was also applied in several other cases, such as "Fecliba vs. Roux Ocefa, Rivero and Fidex" (1998), where three pharmaceutical companies were accused to agree about the prices of their physiological serums; and "Aviabue vs. American Airlines, United Airlines and British Airways" (2001), where three airlines were accused of jointly reducing the commissions that they paid to their travel agents in Argentina ${ }^{11}$.

A few cases, however, ended in fines when the competition authorities found certain ancillary restraints that were capable to restrict competition or to facilitate collusion. One of them is "CNDC vs. Axle and others" (1997), where the main producers of safety-valves for LPG bottles were fined for having agreed to use a single marketing company, which was in charge to decide which firm would sell its product to each customer. Another case, which is more recent and much more important because of the amount of the fine imposed, is "CNDC vs. Loma Negra and others" (2005), where the four cement producers that operate in Argentina were found guilty of collusion. The main proof for that collusion was the existence of an information system, managed by the trade association of cement producers, through which each firm had detailed information about the sales of the other firms in every urban area of Argentina.

\section{Horizontal exclusionary practices}

In the list of anticompetitive practices that appears on article 2 of the Argentine competition act, there are at least three types of conduct that can be

\footnotetext{
${ }^{11}$ This idea about the insufficiency of conscious parallelism to prove the existence of collusion is consistent with the main international antitrust doctrine. In the US, for example, it was endorsed by the Supreme Court when deciding the case "Theatre Enterprises vs. Paramount" (1954), 346 US 537.
} 
considered to be horizontal and exclusionary. These are the ones that appear in paragraphs "f", "l" and "m", which state that practices such as entry deterrence, refusals to sale and predatory pricing can be illegal if they lessen competition or imply an abuse of dominant position, and they damage the general economic interest.

The first case of entry deterrence that was penalized by the CNDC in its history is "A. Savant vs. Matadero Vera" (1982), where the only slaughterhouse in a small city of the province of Santa Fe was found guilty to abuse of its dominant position when it refused to give access to its facilities to a cattle raiser which was at the same time the owner of a butcher's shop that competed against the slaughterhouse. This case is important because it implied the first example of use of the so-called "essential facilities' doctrine" in the Argentine antitrust law ${ }^{12}$, and because it was one of the first cases in which a firm was found guilty of abuse of dominance. Another important case of entry deterrence is "Procter \& Gamble vs. Unilever and others" (1999), where the most important powder soap producer was accused of deterring the entry of a new brand of its main competitor, through the use of unfair advertising. Although the CNDC found that the practice under analysis was probably designed to harm the plaintiff's interests, this case ended without a penalty, since it was also considered that the means used were not enough to deter the entry of the new powder soap brand.

Another entry deterrence case that ended without a penalty, and implied an important precedent for future cases, was "Executive Class vs. Argentine Air Force and Manuel Tienda León" (1998), where the CNDC set a principle that resembles the so-called "Noerr-Pennington doctrine"13. In this case, a taxi-cab company objected a concerted practice between the Argentine Air Force (which was in charge of

\footnotetext{
${ }^{12}$ The essential facilities' doctrine was first applied in the history of antitrust law by the US Supreme Court in 1912, in the sentence that closed the case called "US vs. Terminal Railroad Association", 224 US 383. In Europe, its use is much more modern. Goyder (1998), for example, cites a case of 1992 as the first application of this doctrine by the European Commission ("B\&I vs. Sealink", 5 CMLR 255).

${ }^{13}$ This doctrine originated in the US as a consequence of the cases "Noerr vs. Eastern Railroads" (365 US 127, 1961) and "Pennington vs. United Mine Workers" (381 US 657, 1965). It is a principle under which the actions to influence government decisions (and the government decisions taken as a consequence of that influence) are not illegal, even when they are aimed towards lessening competition or damaging competitors. This is because they are allowed by other laws and regulations different from antitrust law, and may therefore have other policy goals different from the defense of competition.
} 
operating the Argentine airports) and a firm that offered ground transportation services (both through buses and taxi-cabs), through which the former gave exclusivity to the latter to offer its services in the Buenos Aires international airport. Although the CNDC considered that the practice under analysis restricted competition and was unreasonable (since there were no valid reasons to grant exclusivity when several firms could compete to supply their services of ground transportation between the airport and the city of Buenos Aires), it considered that its origin was a regulation issued by the government, which was exempted from antitrust scrutiny. The competition agency, nevertheless, recommended that such regulation was eliminated, but no penalty was applied either to the Air Force or to the accused ground transportation supplier.

The Argentine antitrust case law also has several examples of horizontal exclusionary practices that were carried out by a group of competitors in order to deter other firms to enter a market. Many of those cases had to do with entities that group health service providers, such as physicians' associations and hospitals' associations. The first example of this type is "Staff Médico vs. FeMeBA" (1982), where a private health management organization accused the physicians' association of the province of Buenos Aires to impede its affiliates to work for it, in order to benefit its own health management organization and to deter the plaintiff from entering the market. This case ended with a fine, and was the first of a relatively long list of cases where physicians' and hospitals' associations, which were found to have a dominant position in a certain province or city in Argentina, were penalized for practices aimed at lessening competition.

Very few penalties can be found, conversely, in cases where the plaintiffs objected predatory pricing practices. One example of these is "CNDC vs. Santiago del Estero Bakers' Center and others" (1983), where a group of bakeries were penalized for predatory attitudes towards a competitor. Those attitudes, however, were part of a strategy to monitor a collusive agreement that existed in the city of Santiago del Estero, and the predatory prices were used to discipline the baker's shops that abandoned that collusive agreement. 
But the main predatory pricing case that the CNDC has analyzed (which was “Argentine Chamber of Stationer's Shops vs. Supermercados Makro”, 1997) ended with the opinion that the practice was not anticompetitive. It was about a supermarket chain that sold a stationery product below the price that it paid for it, during a relatively short period of time. Although in this case it was clear that the product was sold below its marginal cost, the CNDC understood that no offense to the competition law existed, since the accused supermarket had a very small market share and had no intention or possibility to exclude competitors ${ }^{14}$. Its practice of selling the product at a very low price was therefore part of a business strategy to attract customers to its outlets, aimed at selling all the other products that were offered by the supermarket.

\section{Vertical restraints}

Despite the fact that the Argentine competition act characterizes the anticompetitive practices following the European antitrust tradition, the appraisal of vertical restraints by the Argentine competition law has always been closer to the criteria applied in the United States than to the criteria applied in the European Union $^{15}$. This is because the Argentine antitrust authorities have tended to consider that vertical restraints were less damaging for competition than horizontal restraints, and they have never issued regulations requiring notification or authorization procedures for those practices (as it occurs in the European Union and in many of its member states).

The first important case of vertical restraints analyzed by the CNDC, however, ended in a penalty that was later reversed by the National Court of Appeals on Criminal Economic Matters. It was "CNDC vs. Acfor and Igarreta" (1983), and the objected behavior was an agreement between two automobile dealers to divide a certain market between them. According to the CNDC, the relevant market in this

\footnotetext{
${ }^{14}$ The standard set by the CNDC in this case resembles the one proposed by Joskow and Klevorick (1979), which is explicitly cited in the CNDC's opinion. It consists of first analyzing the existing market structure, and then appraising the effect of possible below-cost sales only if that structure facilitates the implementation of predatory strategies.

${ }^{15}$ The article 2 of Act 25,156 mentions two kinds of vertical practices that can be seen as examples of anticompetitive conduct (if they fall into the general definition of illegal practices given by article 1), which are resale price maintenance (paragraph "g") and exclusive dealing (paragraph "j").
} 
case was the sale of automobiles of a certain brand (Ford) to government agencies, and the practice was a horizontal collusion between the accused car dealers. The court of appeals, conversely, understood that this was in fact a vertical restraint imposed by the car manufacturer, and that it was reasonable as a way to specialize its dealers in selling its products to specific customers. The court of appeals also understood that the relevant market was larger than the originally analyzed by the CNDC, since it included all the automobile suppliers that operated in Argentina at that time.

After the Acfor-Igarreta decision, the vast majority of the cases that involved vertical restraints ended without penalties, for considering that the objected exclusivity and territorial restraint clauses were in fact means that the firms used to organize its marketing when competing against other firms. A particularly strong application of this criterion appears, for example, in "SADIT and others vs. Massalin Particulares and others" (2000), where the two main tobacco companies that operated in Argentina were accused for having changed their distribution scheme from a system in which their wholesale cigarette distributors were the same to another system in which each wholesale distributor became the exclusive dealer of one of the companies, and there was also territorial exclusivity among each company's distributors. To consider that these practices were not anticompetitive, the CNDC analyzed the business environment in which they took place, and found that in fact they had been the result of a process of increasing competition between the two main tobacco companies (Massalin Particulares and Nobleza Piccardo), which were interested in exerting a closer control of their distribution channels to compete more aggressively for capturing the smokers' preferences. The reduction in the "intrabrand competition" implied by the objected practices, therefore, was more than compensated by an increase in the "interbrand competition" that was taking place at the same time ${ }^{16}$.

The general benevolence of the Argentine competition law towards vertical restraints also applies to cases of maximum resale price maintenance, which is a practice that was never considered illegal in Argentina. The main example of this can

\footnotetext{
${ }^{16}$ This idea is no doubt inspired by the antitrust doctrine that began with the US Supreme Court decision in the case known as "Continental vs. GTE Sylvania" (1977), 433 US 36.
} 
be found in "FECRA and others vs. YPF" (1995), in which the CNDC explicitly stated that the setting of maximum resale prices by a fuel refiner was a means that the refiner had to compete more effectively against other refiners, and that it implied a benefit (and not a damage) to the general economic interest (since it allowed consumers to obtain the fuel products paying lower prices).

Minimum resale price maintenance, conversely, was found to be illegal by the CNDC in the case known as "CNDC vs. TRISA, TSC and others" (2003). In that case, two sports program suppliers signed an agreement with the three main cable television operators of the city of Buenos Aires to set a minimum price at which those TV operators would sell the broadcasting of the main national soccer games to their viewers (on a "pay-per-view" basis). The CNDC understood that the agreement was a way to restrict competition among cable television operators and to create a monopoly rent that was mainly appropriated by the program suppliers. That is why it imposed fines to all the firms that signed the agreement, but those firms appealed the decision before the National Court of Appeals on Criminal Economic Matters. Once again, that court of appeals reversed the administrative decision, arguing that in fact the objected resale price maintenance did not restrict competition between the accused sports program suppliers and other program suppliers that competed against them. In this case, however, the criterion of the court of appeals was not pacifically accepted by the CNDC, and, at the beginning of the year 2007, the case was before the Argentine Supreme Court waiting for a final decision on the issue.

\section{Exploitative abuses of dominant position}

The exploitative abuses of a dominant position are a relatively rare cause of antitrust penalties throughout the world. Moreover, in some antitrust systems they are not even considered as an offense, since they do not create an actual damage to competition but they rather are a situation in which the lack of competition allows a firm to exert its market power more effectively. The countries that follow the US tradition of objecting monopolization practices rather than abuses of dominance, for example, tend to consider that the so-called "exploitative abuses of a dominant 
position" are legal, as long as they do not imply exclusionary practices nor they are prohibited by other regulatory rules ${ }^{17}$.

Following the European tradition, however, the Argentine competition law considers that an abuse of dominant position can occur either by exclusionary or by exploitative reasons, that is, that a dominant firm can be found guilty of abusing its market position if it establishes prices or commercial conditions that are different to the ones that would exist if there was effective competition in the market (and those conditions generate damage to the general economic interest) ${ }^{18}$. The importance of that criterion in the current case law is highly significant, and this is mainly due to the fact that one of the most noticeable cases in the Argentine antitrust history ("CNDC vs. YPF”, 2002) is precisely a case of exploitative abuse of a dominant position.

"CNDC vs. YPF" (2002) is an important case for two reasons. On one hand, it ended with one of the largest fines ever decided in an antitrust case in Argentina ${ }^{19}$. On the other hand, that penalty from the Secretary of Commerce was affirmed by both the National Court of Appeals on Criminal Economic Matters and the Argentine Supreme Court. The issue analyzed in the YPF case was the pricing policy of the defendant concerning its wholesale sales of liquefied petroleum gas (LPG). YPF was the largest supplier of LPG in Argentina, and it was also the largest exporter of that product. The CNDC and the courts that intervened in the case considered that it had a dominant position in the Argentine LPG market, since the other existing suppliers had very minor market shares and YPF was the firm that controlled the majority of the infrastructure needed to supply the product.

The main fact of the YPF case was the evidence that, when selling LPG to foreign buyers, the accused firm charged substantially lower prices than the ones that it charged to domestic buyers (for example, to local LPG distributors), without having

\footnotetext{
${ }^{17}$ The doctrine established by the US Supreme Court in "US vs. Grinnell" (384 US 563, 1966), for example, considers that the two elements that define the offense of monopolization are the possession of monopoly power in the relevant market, and the willful acquisition or maintenance of that power.

${ }^{18}$ This criterion can also be considered as the standard that is applicable in the European Union. See, for example, the decision of the European Court of Justice in "European Commission vs. United Brands" (1 CMLR 429, 1978), where a firm was found guilty of an abuse of dominance for having discriminated among customers located in different European countries.

${ }^{19}$ The imposed fine was equal to 109 million Argentine pesos, which at the time that it was set by the Secretary of Commerce, Industry and Mining (1999) was equivalent to 109 million US dollars.
} 
any justification based on cost or quantity differences. The theory underlying the penalty was that YPF was setting an artificially high domestic price, and that it was restricting the local supply by dumping its product into the foreign markets. This created damage to the general economic interest, because the Argentine LPG consumers ended up with higher prices and smaller quantities than what they would otherwise have, if the objected price discrimination had not taken place ${ }^{20}$.

An interesting novelty that the CNDC introduced in the YPF case was the way in which it calculated the fine to be applied. In order to do this, it estimated the gap between the domestic and the export prices set by the defendant, and multiply that gap by the total amount of LPG sold by YPF in the local market in the period under analysis. That figure was considered to represent the illegal profit obtained by the defendant as a consequence of its abuse of dominant position, which was later increased by $20 \%$ in order to set the actual fine that YPF had to pay.

The Argentine antitrust law also has a few examples of exploitative abuses of dominant position in which the defendants have been punished because of practices that harmed their suppliers rather than their customers. The first case in which this exercise of "monopsony power" was considered illegal was "General Milking Union vs. Popular Cooperative of Santa Rosa" (1982), in which a producer of milk products was fined because of exploitative practices against its milk suppliers. That producer, which was the only buyer of milk in a certain area of the province of La Pampa, was found guilty of discriminating among its suppliers and setting artificially low prices for the milk that it bought from them. Similarly, in "CNDC vs. Industrias Welbers" (1983), a sugar producer was found guilty of abusing of its dominant position against its sugar cane suppliers, because of having set artificially low prices that could only be explained by the buying power that it possessed in the relevant market (which was the Northern area of the province of Santa Fe).

The large majority of cases in which the plaintiffs have objected practices that they considered exploitative abuses of dominant position, however, ended without a

\footnotetext{
${ }^{20}$ Price discrimination is one of the practices cited in article 2 of the Act No. 25,156 that can be considered as examples of exploitative abuses of dominant position (paragraph "k"). Other offenses that can be included in that category and are mentioned in article 2 are abusive pricing (paragraph "g") and tying (paragraph "i").
} 
penalty. In "A. Lafalla vs. Juan Minetti” (2000), for example, the CNDC considered that an increase in the price of cement by the company that had the largest market share in the province of Mendoza was not an exploitative abuse of a dominant position, since the defendant had applied the same increase in all the markets where it operated (without discriminating among areas in which it was presumably dominant and areas in which it was not). Similarly, in "N. La Porta vs. Telefonica and Telecom" (1997), the antitrust authority understood that a price increase by the monopoly suppliers of fixed telephony was not an abuse of dominant position, either, because the increase under analysis had been explicitly authorized and decided by the national telecommunications' regulator.

\section{Horizontal mergers}

The main conclusion that can be derived from analyzing the application of the Act No. 25,156 to merger cases is that, in Argentina, horizontal mergers are prohibited if they create a monopoly in a relevant market. For example, the only two horizontal mergers that have been prohibited by the antitrust authorities since the introduction of the merger notification procedure in 1999 fall into that category, and many cases in which the CNDC recommended structural remedies are also cases in which what it wanted was to avoid the creation of a monopoly in a certain product or geographic market.

The first merger that was prohibited by the Argentine competition authorities was "OCA/Correo Argentino" (2001), which, if approved, would have implied the creation of a monopoly in several postal markets in Argentina. The proposed transaction was in fact the acquisition of the firm that had the concession of the official Argentine post office by its main private competitor, and the CNDC considered that the acquired and the acquiring firm were actually the only two companies that operated in several relevant product markets (the ones referred to

simple letters, special letters, telegrams and banking clearing operations). Although the two firms were also in other markets in which they did face competition from other suppliers (for example, package distribution), those markets were relatively 
unimportant in their total revenues, and it was therefore impossible to authorize the merger for those markets and not for the ones in which competition was going to disappear.

The other horizontal merger that was prohibited in Argentina for antitrust reasons was "Teledigital/Esmeralda-Venado Tuerto Television" (2003), which consisted of the acquisition of the assets of two cable television companies by another company that was their only competitor in the city of Venado Tuerto (in the province of Santa Fe). Although in this case the CNDC analyzed the possible competition between the merging parties and the supplier of a substitute good (which was satellite television), it concluded that such competition was not strong enough, because cable television and satellite television were in fact different relevant markets. The efficiency gains generated by the merger (because of the elimination of overlapping among the companies' networks) were also considered to be insufficient to compensate the damage to competition that the creation of a monopoly would entail. Finally, although the two companies to be acquired were under a bankruptcy process, the CNDC did not accept the use of a "failing firm defense", since it was not the case that the proposed acquiring company was the only candidate to buy the other firms' assets (and, far from that, there was another firm that had presented an offer to buy those assets $)^{21}$.

The same principle of avoiding monopoly situations that appears in the OCA and Teledigital cases can be found in a number of situations where the Argentine antitrust authorities ordered partial asset divestitures. One example of this is "Telefonica/AC Inversora-Atlántida Comunicaciones" (2000), where the acquiring firm was obliged to sell one of the open television channels that operated in the city of Mar del Plata, due to the fact that, as a consequence of this acquisition, the only two open television stations of that city would belong to the same economic group. Similarly, in "Fresenius/RTC" (2000), the acquiring firm had to sell five dialysis

\footnotetext{
${ }^{21}$ The failing firm defense is an argument that the merging companies can invoke if the most probable alternative to the increase in market concentration generated by a merger is the exit of the acquired firm from the market. This defense is explicitly analyzed in the horizontal merger guidelines issued by the US antitrust agencies, but it does not appear in the Argentine merger guidelines approved by Resolution 164/01.
} 
centers located in five Argentine cities (from a total of 95 centers controlled by the newly merged group), because the merger -if unconditioned- was going to generate a situation of monopoly in those cities.

Several structural and behavioral remedies were also imposed by the Argentine antitrust authorities in cases where no monopoly situation was going to appear, but where there was a danger of a concentration increase in a tight oligopoly where possible "coordinated effects" were feared ${ }^{22}$. In those cases, the rule that can be derived from the enforcement of Act 25,156 is that the newly merged entity is usually required to divest certain assets whose size is roughly equivalent to the size of the smallest firm that participates in the merger. In "AmBev/Quilmes" (2003), for example, a Brazilian brewery (AmBev), that already had a market share of approximately $11 \%$ in the Argentine beer market, bought the main Argentine brewery (whose market share in Argentina was around 70\%). The acquisition was approved, subject to the condition that the newly merged firm divested a number of brands and beer plants whose size was approximately equivalent to the one that AmBev had in Argentina before buying Quilmes's stock. The acquirer of those brands and plants, moreover, had to be a firm that did not already operate in the Argentine beer market, in order to foster the entry of a new player to a market that was considered to be highly concentrated.

Another case in which a substantial divestiture was ordered to approve a merger was "Telefonica/BellSouth" (2004), in which the second largest cellular telephone company in Argentina (Telefonica) bought the stock of the third largest firm in the same market (BellSouth). Although in that market (cellular telephone services) there were also two other important firms, the newly merged company was going to concentrate nearly $50 \%$ of the total number of customers. To avoid the possible negative consequences of this, the CNDC decided to approve the merger subject to the condition that Telefonica ceded its rights to use part of the available

\footnotetext{
${ }^{22}$ The possible anticompetitive effects of a horizontal merger can be of two types. On one hand, the newly merged company can exert monopoly power in the relevant market where it operates. This is the main "unilateral effect" of a merger. On the other hand, an increase in the market concentration provoked by a merger can increase the likelihood of collusion among the firms that remain in the market. This is the main "coordinated effect" that the antitrust law tries to avoid when it requires a procedure of merger notification. For a deeper analysis of these issues, see Coloma (2003), chapter 7.
} 
radio electric spectrum to a new entrant to the market (whose size was intended to be roughly equivalent to the one that BellSouth had before selling its stock to Telefonica $)^{23}$.

The imposition of structural conditions to approve horizontal mergers, however, is relatively scarce if markets are not very concentrated, and also in cases of markets where the CNDC considers that entry is relatively easy or international competition is relatively strong. That is the case, for example, of many mergers that affected food product markets. Among the horizontal mergers that were approved without conditions we can cite "Molinos/Lucchetti" (2001), where there was a large increase in concentration in the dry pasta market; "Arcor/Bagley" (2004), where the main concentration increase occurred in the biscuit market; and "Arcor/La Campagnola" (2006), which implied the creation of a quasi-monopoly in the market of jam products.

\section{Vertical and conglomerate mergers}

Although the bulk of the antitrust analysis concerning mergers is in the study of horizontal mergers (that is, mergers among firms that operate in the same relevant market), merger notification procedures are generally applicable to all kinds of mergers, and this includes cases of vertical mergers (that is, mergers among firms that have a real or potential supplier/customer relationship) and conglomerate mergers (that is, mergers that are neither horizontal nor vertical). Most of those mergers are approved without conditions of any kind, and this is true in the majority of the countries of the world and also in Argentina. The Argentine antitrust history, however, has a few cases of vertical and conglomerate mergers that have been subject to structural or behavioral conditions, and one case of a vertical merger that was entirely prohibited.

The only prohibited vertical merger so far in Argentina is "Aeropuertos Argentina 2000/LAPA" (2002). It was a case in which the firm that held the

\footnotetext{
${ }^{23}$ In fact, this requirement was also imposed because of the existence of a specific regulation issued by the Argentine telecommunications' regulatory agency, which prohibited that a single cellular telephone company possessed more than a certain amount of radio electric spectrum in each area of Argentina.
} 
monopoly license to operate all the Argentine airports (Aeropuertos Argentina 2000) tried to acquire the stock of the second largest Argentine airline (LAPA). The competitive danger that this merger posed, according to the CNDC, was the possibility of a vertical foreclosure, and the possible extension of Aeropuertos's monopoly power from the airport business to the domestic air transportation market. That possibility originated in the fact that airports are an essential input to supply air transportation services, and therefore a firm that controls that input, and has also interests in the airline business, has strong incentives to carry out exclusionary practices, in order to monopolize the domestic air transportation market. That was particularly true in the case under analysis, because the regulation to which Aeropuertos Argentina 2000 was subject to supply airport services was relatively lax, and the main competitor of LAPA in the Argentine air transportation market (which was the firm Aerolineas Argentinas) was in a process of reorganization.

Another important vertical merger analyzed by the CNDC was "Liberty Media-Hicks/Cablevision" (2001), in which the two acquiring firms (Liberty Media and Hicks) already owned several pay television channels, and the acquired company (Cablevision) was one of the largest cable TV operators in Argentina. The main concern of the competition authority in this case was the possibility of exclusionary practices against other television channel suppliers and other cable television operators. To reduce the possibility of those practices, the merger was approved subject to the condition that the newly merged entity should warrant the availability of the television channels controlled by Liberty Media and Hicks, in fair commercial terms, to all those television operators who requested them. Similarly, the grid of Cablevision should also be available, in fair commercial terms, for the television channel suppliers that competed against Liberty Media and Hicks in the markets of television contents.

Most other vertical mergers, however, posed very little anticompetitive concerns due to the fact that either the acquiring firm or the acquired company had a relatively small share in the relevant markets where they operate. In those cases, the rule seems to be that the Argentine antitrust authorities approve the mergers without 
imposing any structural or behavioral remedy. Examples of those transactions are "Totalinef/TGN" (2000), which was a partial merger between a natural gas producer and a natural gas transporter; "Maersk/Terminal 4" (2001), which was a merger between an international shipping company and the firm that had the concession of one of the harbors in the port of Buenos Aires; and "NewsCorp/DirecTV" (2005), which was a merger between a television channel supplier and a satellite television operator.

If vertical mergers are usually unable to damage competition, the same can be said about most conglomerate mergers. In the relatively short history of antitrust merger control in Argentina, for example, there are no cases of conglomerate mergers that have been prohibited or substantially conditioned. Among the conglomerate mergers that the CNDC has analyzed, it is worth mentioning several cases of "market extension mergers" (that is, mergers among firms that operate in the same business but in different markets), which were in all cases approved without restrictions. Examples of those cases are "Teledigital/Las Heras Television" (2000), which was a merger between two cable TV operators that were located in different urban areas; "Petrobras/Eg3" (2001), which was the acquisition of an Argentine fuel refiner by a Brazilian refiner that was not previously operating in Argentina; and "Pepsi/Quaker" (2001), which was the acquisition of a cereal producer by a firm that already operated in several food product markets but not in the cereal market.

The Argentine competition law does not have any provision that establishes a distinction between mergers in which the parties are local firms and mergers in which one or several of them are foreign firms. There is one conglomerate merger case, however, in which that distinction was analyzed by the CNDC, concerning the acquisition of a firm that controlled the main electricity transportation company of Argentina (Transener) by a Brazilian firm (Petrobras). That occurred in the case called "Petrobras/Pérez Companc" (2003), in which, although the CNDC explicitly disregarded the argument of nationality as a possible competition problem, the Secretary of Competition Defense accepted a commitment offered by the acquiring firm to sell its share in Transener's stock. 


\section{Concluding remarks}

The analysis of the Argentine competition law and its enforcement, which we have made in the previous sections, can be summarized through a series of concluding remarks. These are the following:

a) The Argentine competition law evolved from a system that was inspired in the US antitrust law and was predominantly based on judicial enforcement, to a scheme which is closer to the European competition principles and is mainly enforced by a single administrative antitrust agency. That system has produced a relatively coherent case law, whose standards are a combination between US antitrust principles and European criteria.

b) The main distinctive characteristic of the Argentine competition law is its reference to the fact that anticompetitive practices and mergers can be illegal only if they are able to generate damage to the "general economic interest". This concept has been assimilated to the economic concept of "total surplus" generated in a market, and it also refers to the idea that in the Argentine antitrust system there are no practices that can be considered illegal per se.

c) Most overt collusion practices, however, have been penalized without actually proving the existence of a real damage to the general economic interest, but simply arguing that they worsen the situation that consumers would have in the absence of the objected collusive agreement.

d) On the contrary, when there are ancillary restraints that may facilitate collusion or act as collusive devices, the damage to the general economic interest has to be more carefully proven, since those restraints can also be explained by efficiency reasons. The same occurs in cases of covert collusion, where the main idea that stems from the cases analyzed by the Argentine antitrust authorities is that conscious parallelism is not enough to prove the existence of a collusive practice.

e) Due to the way in which the Argentine competition act is worded, the practices that are considered anticompetitive because of exclusionary reasons can be challenged either as a lessening of competition or as an abuse of dominant position. The 
Argentine case law about them is nevertheless rather conservative, in the sense that both entry deterrence and predatory conduct are punished only if it is clear that there is a practice whose single possible explanation is the exclusion of competitors, and it is extremely likely that it suffices to actually exclude those competitors from the market.

f) The Argentine competition law has also been very cautious to penalize vertical restraints, especially in cases of exclusive dealing and exclusive territories. Maximum resale price maintenance has also been considered legal in all the cases analyzed by the Argentine antitrust authorities, but minimum resale price maintenance has been considered illegal when it helped to sustain collusion among downstream competitors and when it helped to extend the upstream supplier's monopoly power.

g) Another noticeable characteristic of the Argentine antitrust law is the prosecution of cases of exploitative abuse of dominant position, some of which have ended with substantial fines. The main rule that can be derived from those cases is that price discrimination can be illegal if it is practiced by a dominant firm to enhance its market power, and if it generates a damage to the general economic interest that is translated into a price increase that harms domestic consumers or into a price reduction that harms local suppliers.

h) Since 1999, the Argentine competition system introduced a merger notification procedure whose rules are similar to the ones that exist in the United States. As a consequence of that procedure, several horizontal mergers that would have created a monopoly in a relevant market have been prohibited or severely conditioned. Other mergers, that did not create a monopoly but substantially increased concentration in markets with large entry barriers, have also been subject to structural remedies, such as the obligation to divest assets which are enough to compensate that concentration increase.

i) Vertical mergers have also been subject to some prohibitions and objections, but only when they involved an undertaking with substantial monopoly power and created a large risk of vertical foreclosure and market power extension. Conglomerate mergers, finally, have never been prohibited or conditioned by the Argentine antitrust 
authorities, although there is a case in which there was a "tacit objection" to the fact that a foreign company bought a local firm that controlled an essential facility in the electricity sector.

\section{Appendix: Excerpts from the Act No. 25,156 ${ }^{24}$}

Article 1. Actions and practices related to the production or trade of goods and services that lessen, restrict or distort competition or constitute an abuse of a dominant position in a market, in a manner that may result in damage to the general economic interest, are prohibited and will be penalized pursuant to the rules of this Act.

Article 2. The following practices, among others, to the extent that they configure the hypotheses of article 1, constitute practices that lessen competition:

a) Fixing, agreeing or handling either directly or indirectly the selling price or purchase of goods or services at which they are offered or purchased in the market, as well as exchanging information with the same purpose or to the same effect;

b) Establishing the obligation of producing, processing, distributing, purchasing or marketing only a limited amount of goods or rendering a limited number, volume or frequency of services;

c) Sharing horizontally areas, markets, customers or supply sources;

d) Concerting or co-ordinating bids in auctions or contests;

e) Concerting the limitation or control of technological development or investments made for the production or marketing of goods and services;

f) Preventing, hampering or obstructing the entry or permanence of persons in a market or excluding them from such market;

g) Fixing, imposing or practicing, directly or indirectly, in agreement with competitors or individually, any form of price and purchase conditions or of sale of goods, furnishing of services or production;

h) Regulating goods or services markets by means of agreements in order to restrict or control technological research and development, the production of goods or the furnishing of services or hindering investments made in the production of goods or services or in their distribution;

i) Subordinating the sale of goods to the purchase of other goods or to the use of a service, or subordinating the furnishing of services to the use of other service or to the purchase of goods;

j) Subordinating the purchase or sale to the condition of not using, purchasing, selling or supplying goods or services, produced, processed, distributed or marketed by a third party;

k) Imposing discriminatory conditions for the purchasing or transfer of goods or services without reasons based on usual business practices;

1) Refusing, without justified cause, to satisfy effective orders for the purchase or sale ${ }^{24}$ The only official version of the Act No. 25,156 is the Spanish version. This English translation is
therefore unofficial. 
of goods or services, under the conditions prevailing in the relevant market;

11) Discontinuing the provision of a dominant monopolistic service in the market to a public utility or public interest service provider;

m) Transferring goods or furnishing services at prices lower than their cost, without reasons based on usual business practices in order to remove competitors from the market or to damage the image, property or trademark value of its good or service suppliers.

Article 4. For the purposes of this Act, it is understood that one or more persons enjoy a dominant position when, for a certain type of product or service, that person is the only supplier or buyer in the national market or in one or several parts of the world, or when, without being the only one, he or she is not exposed to substantial competition or when, because of the vertical or horizontal degree of integration, he or she is able to determine the economic feasibility of a competitor or participant in the market, to the latter's detriment.

Article 5. In order to establish a dominant position in a market, the following circumstances shall be considered:

a) The extent to which the relevant goods or services may be replaced by other national or foreign goods or services, and the conditions and time required for such replacement;

b) The extent to which regulatory restrictions limit the access of products or suppliers or buyers to the relevant market;

c) The extent to which an undertaking has the power to unilaterally affect prices or to restrict the supply or demand in the market, and the extent to which its competitors are able to offset that power.

Article 7. Mergers and other economic concentration transactions, whose object or effect is or may be to lessen, restrict or distort competition, in a manner that may result in damage to the general economic interest, are hereby prohibited.

\section{References}

Cabanellas, Guillermo (2005). Derecho antimonopólico y de defensa de la competencia [Antitrust and Competition Defense Law], 2nd edition; Buenos Aires, Heliasta.

CNDC (1997). "Breve análisis económico de la ley argentina de defensa de la competencia" [Brief Economic Analysis of the Argentine Competition Defense Act]; Buenos Aires, Department of Commerce, Industry and Mining.

Coloma, Germán (2003). Defensa de la competencia [Competition Defense]; Buenos Aires, Ciudad Argentina.

Goyder, D. G. (1998). EC Competition Law, 3rd edition; Oxford, Oxford University Press. 
Joskow, Paul and Klevorick, Alan (1979). "A Framework for Analyzing Predatory Pricing Policy”; Yale Law Review, vol 89, pp 213-270.

Neumann, Manfred (2001). Competition Policy; Cheltenham, Edward Elgar.

OECD (2006). Competition Law and Policy in Argentina: A Peer Review. Paris, Organization for Economic Cooperation and Development.

\section{Table of cases}

Aeropuertos Argentina 2000/LAPA (2002), Resolution 29/02 from the Secretary of Competition Defense.

AGP vs. CCAP and others (1996), Resolution 382/96 from the Secretary of Commerce, Industry and Mining.

AmBev/Quilmes (2003), Resolution 5/03 from the Secretary of Competition Defense.

Arcor/Bagley (2004), Opinion 403 of the National Commission for the Defense of Competition.

Arcor/La Campagnola (2006), Opinion 569 of the National Commission for the Defense of Competition.

Argentine Chamber of Stationer's Shops vs. Supermercados Makro (1997), Resolution 810/97 from the Secretary of Commerce, Industry and Mining.

Aviabue vs. American Airlines, United Airlines and British Airways (2001), Resolution 115/01 from the Secretary of Competition Defense.

CNDC vs. Acfor and Igarreta (1983), Opinion 40 of the National Commission for the Defense of Competition, Sentence of the National Court of Appeals on Criminal Economic Matters, Room 1, 27/Dec/1983.

CNDC vs. Air Liquide and others (2005), Opinion 510 of the National Commission for the Defense of Competition.

CNDC vs. Axle and others (1997), Resolution 730/97 from the Secretary of Commerce, Industry and Mining.

CNDC vs. Industrias Welbers (1983), Resolution 102/83 from the Secretary of Commerce, Sentence of the National Court of Appeals on Criminal Economic Matters, Room 2, 5/Jul/1983.

CNDC vs. Loma Negra and others (2005), Resolution 124/05 from the Secretary of Technical Coordination.

CNDC vs. Santiago del Estero Bakers' Center and others (1983), Resolution 319/83 from the Secretary of Commerce.

CNDC vs. TRISA, TSC and others (2003), Resolution 28/02 from the Secretary of Competition Defense, Sentence of the National Court of Appeals on Criminal Economic Matters, Room B, 29/Aug/2003. 
CNDC vs. YPF (2002), Resolution 189/99 from the Secretary of Commerce, Industry and Mining; Sentence of the Argentine Supreme Court, 2/Jul/2002.

Department of Energy vs. YPF, Esso and Shell (1994), Resolution 99/94 from the Secretary of Commerce.

Executive Class vs. Argentine Air Force and Manuel Tienda León (1998), Opinion 282 of the National Commission for the Defense of Competition.

Fecliba vs. Roux Ocefa, Rivero and Fidex (1998), Resolution 211/98 from the Secretary of Commerce, Industry and Mining.

FECRA and others vs. YPF (1995), Resolutions 8, 30-31 and 159-161/95 from the Secretary of Commerce.

Fresenius/RTC (2000), Resolution 83/00 from the Secretary of Competition Defense.

General Milking Union vs. Popular Cooperative of Santa Rosa (1982), Resolution 178/82 from the Secretary of Commerce.

A. Lafalla vs. Juan Minetti (2000), Resolution 309/00 from the Secretary of Competition Defense.

N. La Porta vs. Telefonica and Telecom (1997), Resolution 337/97 from the Secretary of Commerce, Industry and Mining, Sentence of the National Court of Appeals on Criminal Economic Matters, Room A, 4/Jul/1997.

Lara Gas and others vs. Agip and others (1993), Opinion 118 of the National Commission for the Defense of Competition, Sentence of the Argentine Supreme Court, 23/Nov/1993.

Liberty Media-Hicks/Cablevision (2001), Resolution 2/01 from the Secretary of Competition Defense.

Maersk/Terminal 4 (2001), Resolution 17/01 from the Secretary of Competition Defense.

Molinos/Lucchetti (2001), Resolution 33/01 from the Secretary of Competition Defense.

NewsCorp/DirecTV (2005), Resolution 49/05 from the Secretary of Technical Coordination.

OCA/Correo Argentino (2001), Resolution 64/01 from the Secretary of Competition Defense.

Pepsi/Quaker (2001), Resolution 9/01 from the Secretary of Competition Defense.

Petrobras/Eg3 (2001), Resolution 150/01 from the Secretary of Competition Defense.

Petrobras/Pérez Companc (2003), Resolution 62/03 from the Secretary of Competition Defense.

Procter \& Gamble vs. Unilever and others (1999), Resolution 884/99 from the Secretary of Commerce, Industry and Mining. 
SADIT and others vs. Massalin Particulares and others (2000), Resolution 281/00 from the Secretary of Competition Defense.

A. Savant vs. Matadero Vera (1982), Resolution 78/82 from the Secretary of Commerce.

Silos Areneros de Buenos Aires vs. Arenera Argentina and others (1986), Resolution $442 / 86$ from the Secretary of Commerce.

Staff Médico vs. FeMeBA (1982), Resolution 101/82 from the Secretary of Commerce.

Teledigital/Esmeralda-Venado Tuerto Television (2003), Resolution 32/03 from the Secretary of Competition Defense.

Teledigital/Las Heras Television (2000), Resolution 32/00 from the Secretary of Competition Defense.

Telefonica/AC Inversora-Atlántida Comunicaciones (2000), Resolution 53/00 from the Secretary of Competition Defense.

Telefonica/BellSouth (2004), Opinion 417 of the National Commission for the Defense of Competition.

Totalinef/TGN" (2000), Resolution 267/00 from the Secretary of Competition Defense. 